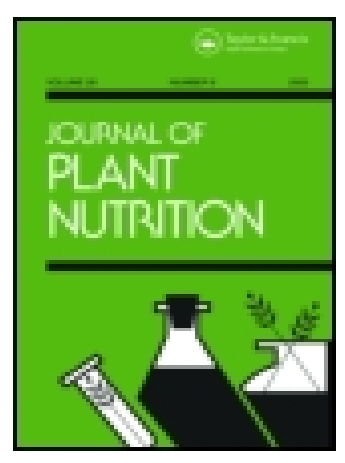

Journal of Plant Nutrition

ISSN: 0190-4167 (Print) 1532-4087 (Online) Journal homepage: http://www.tandfonline.com/loi/lpla20

\title{
Effects of Sprayed Humic Acid, Iron and Zinc on Quantitative and Qualitative Characteristics of Niger Plant (Guizotia abyssinica L.)
}

\section{Ali Tadayyon, Sedigheh Beheshti \& Mohammad Pessarakli}

To cite this article: Ali Tadayyon, Sedigheh Beheshti \& Mohammad Pessarakli (2017): Effects of Sprayed Humic Acid, Iron and Zinc on Quantitative and Qualitative Characteristics of Niger Plant (Guizotia abyssinica L.), Journal of Plant Nutrition, DOI: 10.1080/01904167.2016.1270321

To link to this article: http://dx.doi.org/10.1080/01904167.2016.1270321

Accepted author version posted online: 25

Jan 2017.

Submit your article to this journal $[\pi$

Q View related articles ¿

View Crossmark data \lceil 


\title{
ACCEPTED MANUSCRIPT
}

\section{Effects of Sprayed Humic Acid, Iron and Zinc on Quantitative and Qualitative}

\section{Characteristics of Niger Plant (Guizotia abyssinica L.)}

\author{
Ali Tadayyon, ${ }^{1}$ Sedigheh Beheshti ${ }^{2}$ and Mohammad Pessarakli ${ }^{3 *}$ \\ ${ }^{1}$ Associate Professor, Agronomy Department, Faculty of Agriculture, Shahrekord University. P. \\ O. Box 115, Postal code 88186/34141, Shahrekord, Iran \\ ${ }^{2}$ MSc. student, Agronomy Department, Faculty of Agriculture, Shahrekord University. P. O. \\ Box 115, Postal code 88186/34141, Shahrekord, Iran, \\ ${ }^{3}$ Professor, College of Agric. \& Life Sciences, The University of Arizona, Tucson, Arizona, \\ USA
}

Address Correspondence to Mohammad Pessarakli: pessarak@email.arizona.edu

\begin{abstract}
In order to investigate the effect of foliar application of organic fertilizer and micronutrients on quantitative and qualitative characteristics of Niger plant, a field experiment was conducted in a complete randomized block design with three replications at Shahrekord University Research Farm during the years 2013-2014. Treatments included three levels of humic acid (1, 3, and 6 liters of humic acid per hectare), iron ( 4 parts per million, ppm), zinc ( 4 parts per million, ppm)
\end{abstract}




\section{ACCEPTED MANUSCRIPT}

and control (without humic acid iron, and zinc). In this experiment, traits of the number of heads per plant, seeds number per head, 1000 seeds' weight, grain yield, and also oil and protein content were evaluated. The findings showed that foliar application of humic acid, zinc and iron resulted in a significant increase in all analyzed traits. The most significant plant response was obtained with the use of 6 liters humic acid per hectare, and the second most significant plant response was seen with the sprayed zinc treatment which was probably due to limited absorption and deficiency of these elements in the tested soil.

Keywords: Microelement, Bio-fertilizer, Oil Content, Niger plant. 


\section{ACCEPTED MANUSCRIPT}

\section{INTRODUCTION}

Niger plant is an oil seed crop (Guizotia abyssinica L.) with a genus of Guizotia, Compositae family, Heliantheae class and Coreopsidinae order. This is a diploid $(2 \mathrm{n}=30)$, dicotyledonous, annual plant which its foliage is relatively high. On average, its height ranges from 1.4 to 2 meters depending on the environmental conditions. During the growing season, it needs a temperature range of 15 to $23^{\circ} \mathrm{C}$ and at least $500 \mathrm{~mm}$ of rainfall (Getinet and Sharma, 1996). The percentage of its seed oil content is 29 to 44 percent, containing 66 to 70 percent linoleic acid (Getinet and Sharma, 1996).

Niger plant is a multipurpose plant that has been imported to Iran which its seeds are used as bird food. Nonetheless, due to its good economic value and possibility of exporting its seeds, this plant has been recently highly demanded by the farmers. In this regard, methods that accelerate further development of the plant cultivation in diverse regions would be required. One of the major necessities in crop planning for high yield and quality achievement is the evaluation of plant nutrition systems. Because of the problems such as calcareous of the agricultural soils, bicarbonate content of the irrigation water, low organic matter, and excessive consumption of the phosphate fertilizers, Iran's soils in general have severe deficiency of micronutrients, especially zinc and iron. According to Marschner (1993), in arid regions' soils encountering zinc and iron deficiency, soil application of zinc and iron are not effective. Instead, foliar application of such nutrients in early growth period of grain crops would increase their performance. According to the report of Graham et al. (1992), micronutrients' deficiency in calcareous soils of arid and semi-arid areas is considered as growth restriction factors for many oilseeds. Consequently, 


\section{ACCEPTED MANUSCRIPT}

many researchers have reported positive effects of micronutrients' foliar application, especially iron and zinc on oil seed crops. Findings have demonstrated that spraying of micronutrients such as zinc and iron significantly increases the number of seeds per head, 1000 seeds' weight, grain yield, oil and protein content in safflower (Ravi et al., 2008) and also enhances 1000 seeds' weight, grain yield, and oil content in the canola (Bahrani, 2015). Jackson and Hamson (2000) have also reported a positive influence of Zinc sulfate application on the grain yield and oil content of colza. In another experiment application of Zinc sulfate by foliar spraying, the oil yield and content of mustard increased (Malewar et al., 2001).

Accordingly, in order to approach sustainable agriculture, a proper application of plant nutrition while preserving the environment, increasing the efficiency of inputs through avoidance of the use of unnecessary and excessive nutrients' intake could be suggested. In this respect, applying a very small amount of organic acids via humus compounds increases the production and improves the quality of agricultural products. Humus compounds contain two important types of organic acids named humic and folic acid. Humic acid is a commercial product that contains many nutrients including $44-58 \%$ carbon, $46-42 \%$ oxygen, $6-8 \%$ hydrogen, and $4-5 \%$ Nitrogen, as well as many other elements which promote plant growth (Larcher, 2003). It can also have a direct positive effect on plant growth. Both shoots' and roots' growth are stimulated by humic acid; while, roots are more affected by humic acid (Albiach et al. 2001). Thus, by application of humic acid, root volume rises and as a result, the root system performs better and more effectively; so that, nutrient uptake would be significantly boosted in the plants (Nardi et al., 2002). Moraditochaee (2012) and Rajpar et al (2011 also reported seed yield and oil content increased in the presence of humic acid in peanut and turnip, respectively. 


\section{ACCEPTED MANUSCRIPT}

Spraying micro-nutrients and biological compounds plays a crucial role in achieving the goals of sustainable agriculture and considering the role of oil seeds in its various usages and great importance of Niger plant as a new crop, thus, the necessity of this research will be highlighted. Therefore, the aim of this project is to investigate the effects of humic acid applied as an organic matter, iron and zinc as micronutrient elements on Niger plant yield as a new crop species produced in Shahrekord climate.

\section{MATERIALS AND METHODS}

In order to evaluate the effect of foliar application of humic acid, zinc $(\mathrm{Zn})$ and iron $(\mathrm{Fe})$ on traits of Niger plant, a field experiment was conducted in a randomized complete block design with three replications at the Research Station of Shahrekord University in 1994. Treatments included six levels of foliar application included 3 levels of humic acid (110, 330, and $660 \mathrm{ppm})$, iron (4 ppm), zinc (4 ppm) and control (without application of humic acid, $\mathrm{Zn}$, and Fe).

At first, by sampling soil from zero to $30 \mathrm{~cm}$ soil depth, physical and chemical properties of the soil were determined (Table 1).

Seeds were supplied from Isfahan PakanBazr Company. Seeds were sown after plowing and leveling the land in wet soil after reaching the optimum soil temperature of $10^{\circ} \mathrm{C}$, in both sides of $60 \mathrm{~cm}$ row space, $10 \mathrm{~cm}$ within the row space and with a depth of $2 \mathrm{~cm}$, in plots of $2 \times 3$ $\mathrm{m}^{2}$. During the growth period, required care such as watering, spraying, use of urea as side dressing, and weed control were carried out manually. Treatments were applied in two phases during the vegetative growth (14 days) and before flowering. For maximum absorption of 


\section{ACCEPTED MANUSCRIPT}

sprayed solutions by plants, spraying was applied one or two days before irrigation. Humic acid source used in this study contained a liquid phase in a 4-liter bottle package with the commercial name of humins ultrafiltration. This liquid consisted of $12 \%$ humic acid, $3 \%$ folic acid and $3 \%$ potassium oxide with the density of 1 (110 ppm humic acid), 3 (330 ppm humic acid), and 6 (660 ppm humic acid) liters per hectare, respectively. Furthermore, iron and zinc were prepared in the form of $13.2 \%$ iron chelate and $15 \%$ zinc chelate and were applied for each element at a concentration of 4 per thousand (4 $\mathrm{kg}$ per hectare).

Harvesting was performed with the elimination of margins after completing the plant growth and development and when the lower leaves and stems became brown. To do that, from each plot 15 plants were randomly selected, cut, transferred to the laboratory, and required traits were measured. Protein percentage was measured using Kjeldahl and oil content percent was calculated with the use of Soxhlet method.

Eventually, Data were analyzed by SAS statistical software and significant means at 5\% probability were compared by LSD statistical test.

\section{RESULTS AND DISCUSSION}

\section{Head Number per Plant}

The number of heads per plant is one of the important factors of Niger plant yield that is significantly affected by humic acid and micronutrients (Table 2). Humic acid clearly increased the number of heads per plant. More specifically, compared to the control group, along with 


\section{ACCEPTED MANUSCRIPT}

increasing humic acid concentration, the number of heads per plant increased up to 19,36 , and 53 percent, respectively. Thereafter, each humic acid level was placed separately in a different statistical category. Iron and zinc, also increased the number of heads per plant compared to the control plants by 31 and 37 percent, respectively. Iron and zinc treatments did not significantly differ when three liters per ha of humic acid was applied (Table 2).

Ayas and Gulser (2005) reported that humic acid increased biomass production and the lateral branches through increasing the nitrogen content and survival rate of leaves that resulted in enhancing the number of heads per plant. Zinc also has a positive impact on the growth of young shoots, leafs and flower buds. Iron is an essential element for chlorophyll production in green plants and chlorophyll increase causes leaf surface indicator enhancement and consequently dry weight increase (Mariotti et al., 1996). Ravi et al. (2008) reported an increase in the number of heads per plant in safflower by spraying iron and zinc; where, Ebrahimian and Bybordi (2011) claimed an increase in sunflower seed via spraying zinc.

\section{Seed Number per Head}

Number of seeds per pod was significantly affected by spraying humic acid, iron and zinc (Table 2). The mean comparison showed that the application of zinc produced maximum seeds per head (50\% increase) compared to the control group; where, the application of six liters per hectare of humic acid with 38.6 percent increase in the number of seeds per pod, did not differ significantly with the control plants. Other levels of humic acid had no significant difference among each other and not with the use of iron (Table 3). 


\section{ACCEPTED MANUSCRIPT}

Zinc has the main role in the process of pollination, formation of male and female reproductive organs, and grain formation process (Ziaeyan and Rajaie, 2009). Ravi et al. (2008) in their research on safflower and Ebrahimian and Bybordi (2011) in their project on sunflower obtained similar results with regard to raising the number of seeds per head with spraying iron and zinc. Humic and folic acid also resulted in formation of stable complexes and insoluble and soluble complexes with micronutrients and also enhanced absorption of elements such as iron and zinc (Nardi et al., 2002). In a similar experiment, humic acid was applied on durum wheat and increased the fertility of spike. Likewise, it increased photosynthetic activity of the plant by elevating the function of rubisco enzyme (Delfine et al., 2005).

\section{Seeds' Weight}

Sprayed iron, zinc and humic acid resulted in a significant increase in Niger plant grain weight (Table 2). The highest 1000 seeds' weight was observed by using six liters of humic acid (with an increase of $23 \%$ in 1000 seeds weight compared to the control group). This result was not significantly different from application of zinc and humic acid with three liters per hectare. Grain weight increases under foliar application of micronutrients of iron and one liter per hectare humic acid were 12.5 and 11.2 percent, respectively, which were nearly similar in comparison to the control group.

As it was mentioned earlier, it seems that humic acid increases the photosynthetic activity of plants through acceleration of rubisco enzyme. In addition, by improving the production of sugar, protein and vitamins in plant, humic acid positively affects various aspects of 


\section{ACCEPTED MANUSCRIPT}

photosynthesis and improves the quantity and quality of the food crops (Delfine et al., 2005). Aydin et al. (1999) studied the effect of potassium humate on dry matter weight, elements' composition, and nutrients' uptake in sunflower. The results showed that the effect of potassium humate on dry matter weight, yield and production of essential elements in plant is significant. Grain weight increase was because of the role of zinc and iron nutrient elements in formation and accumulation of hydrocarbons and photosynthesis elements in grain. In this regard, auxin biosynthesis increase, chlorophyll concentration, Phospho Inol Pyruvate carboxylase, sodium accumulation decrease in plant tissues, and efficiency enhancement of nitrogen and phosphorus absorption in the presence of zinc, are assumed as factors promoting this trait (Wang and Jin, 2007). In these circumstances, more chlorophyll and IAA production could cause a delay in plant aging and burnout and prolong the duration of photosynthesis. This function improves carbohydrate production and supports its transfer to boost seedlings growth and yield production. In similar experiments, iron and zinc spray increased 1000 seeds' weight in canola (Bahrani, 2015) and in sunflower (Ebrahimian and Bybordi, 2011).

\section{Grain Yield}

Variance analysis (Table 2) showed that spraying of humic acid, Zinc, and Iron significantly increased grain yield at $1 \%$ probability level. According to Table 3, the highest yield (1019 $\mathrm{kg} /$ ha) was observed with spraying six liters per hectare humic acid which was not significantly different from the yield observed with zinc application $(955 \mathrm{~kg} / \mathrm{ha})$. Sprayed iron resulted in 


\section{ACCEPTED MANUSCRIPT}

$87 \%$ yield increase; however, there was no significant difference between the use of one and three liters of humic acid per hectare (Table 3).

Humic acid amplified permeability of cell membrane and, thereby, facilitated the entrance of $\mathrm{K}$ into the cell which accordingly raises the pressure inside the cell and cell division. On the other hand, increasing energy inside the cells would lead to chlorophyll production and Photosynthesis rate increase. After that important factor in the growth process, nitrogen absorption into the cells is intensified and nitrate production is diminished and finally the production is improved (Giasuddin et al., 2007). Moraditochaee (2012) in his experiment on peanut and Rajpar et al. (2011) in their research on turnip, obtained similar grain yield results in the presence of humic acid.

Foliar zinc application also increased hydrocarbon reserves and the longevity of pollen that ultimately led to pollination increase and formation of a greater number of seeds per head. Zinc also involved in protein synthesis of pollen tube leading to pollination and fruit set and seed increase and ultimately yield increase (Wang and Jin, 2007). Similarly, Ebrahimian and Bybordi (2011) also achieved sunflower yield increase with application of zinc and Bahrani (2015) obtained the same findings in colza with application of zinc and iron.

\section{Oil Content}

The trait of seed oil content became significant under the influence of humic acid, iron and zinc treatments (Table 2). The mean comparison showed that the application of zinc and six liters humic acid per hectare increased seed oil content up to 16.9 and 16.2 percent, respectively, and was significantly greater than the control group. The lowest rate of oil content was observed in 


\section{ACCEPTED MANUSCRIPT}

control treatment, while the oil content produced in other treatments (one and three liters per hectare humic acid and iron) showed no significant difference (Table 3). The main advantages of humic acid can be attributed to chelate property of elements such as sodium, potassium, magnesium, zinc, calcium, iron, copper and other elements which compensates nutrient deficiency and as a result promotes fertility and production (Verlinden et al., 2009). Many researchers have claimed oil content increase in the presence of humic acid, iron and zinc. Rajpar et al. (2011) observed an increase in the oil content of Brassica compestris by humic acid application. Bahrani (2015) also reported an increase in canola seed by spraying iron and zinc.

\section{Protein Content}

Variance analysis (Table 2) illustrated that foliar application of humic acid, Iron, and Zinc significantly increased protein content at $1 \%$ probability level. According to mean comparison (Table 3), the highest protein content was observed in six liters per hectare of humic acid treatment with a 31 percent protein content increase compared to the control group. This treatment revealed that there was no significant difference between protein content obtained by the use of one and three liters humic acid per hectare. Application of one and three liters humic acid per hectare showed significant difference in protein content compared to the control group. Application of iron also increased protein content by 19.8 percent compared to the control group. Again, there was not any significant difference in protein content between application of one and three liters humic acid per hectare.

In addition, humic acid increased the protein content by improving nutrient absorption and the ease of absorption of macro and micro elements (Eneji et al., 2013). In the field 


\section{ACCEPTED MANUSCRIPT}

experiments, foliar application of humic acid on sesame also increased protein content (Salwa, 2011). Foliar application of iron affected the amount of active iron uptake and Nitrate Reductase enzyme activity that is essential for amino acids' cycle (Pourgholam et al., 2013). Increase in grain protein with iron application in colza (Pourgholam et al., 2013) and increase in that trait with iron and zinc application in safflower (Ravi et al., 2008) were also reported.

\section{CONCLUSIONS}

The results of this research showed that spraying humic acid and micronutrients increases yield, yield components, protein, and oil content in Niger plant. Furthermore, initially the use of six liters humic acid per hectare and then zinc had the highest effects on cited traits, respectively. It could be concluded that due to the low zinc and iron rate in the soil and high soil $\mathrm{pH}$, zinc and iron absorption efficiency decreases in the soil and spraying the plant compensates these elements. In other words, humic acid has a particular influence on plants which is increase in absorption efficiency of these elements and other micro and macro elements. Therefore, humic acid and micronutrients' leaf foliar application in the soils with aforementioned conditions are recommended which are also in line with the objectives of sustainable agriculture.

\section{ACKNOWLEDGEMENTS}

The authors would like to appreciate the Research Center of Shahrekord University for their encouragement and support for this study. 


\section{ACCEPTED MANUSCRIPT}

\section{REFERENCES}

Albiach, R., R. Canet, F. Pomares, and F. Ingelmo. 2001. Organic matter components aggregate stability and biological activity in a horticultural soil fertilized with different rates of two sewage sludges during ten years Bioresource Technology 77: 109-114.

Ayas, H., and F. and Gulser. 2005. The effect of sulfur and humic acid on yield components and macronutrient contents of spinach (Spinacia oleracea Var. Spinoza). Journal of Biological Science 5(6): 801-804.

Aydin, A., M. Turan, and Y. Sezen. 1999. Effect of fulvic+humic application on yield nutrient uptake in sunflower (Heliantus annuus) and corn (Zea mays). Soil Science 6: 249-252.

Bahrani, A. 2015. Effect of some micro and macro nutrients on seed yield and oil content of rapeseed (Brassica Napus L.). International Journal of Chemical, Environmental and Biological Sciences 3(1): 71-74.

Delfine, S., R. Tognetti, E. Desiderio, and A. Alvino. 2005. Effect of foliar application of N and humic acids on growth and yield of durum wheat. Agronomy for Sustainable Development 25:183-191.

Ebrahimian, E. and A. Bybordi. 2011. Effect of Iron Foliar Fertilization on Growth, Seed and Oil Yield of Sunflower Grown under Different Irrigation Regimes. Middle-East Journal of Scientific Research 9(5): 621-627.

Eneji, A. E., R. Islam, P. An, and U. C. Amalu. 2013. Nitrate retention and physiological adjustment of maize to soil amendment with superabsorbent polymers. Journal of Cleaner Production 52: 478-480. 


\section{ACCEPTED MANUSCRIPT}

Getinet, A. and S.M. Sharma. 1996. Niger Guizotia abyssinica (L. f.) Cass. International Plant Genetic Resources Institute $59 \mathrm{p}$.

Giasuddin, A. B., M. S., Kanel, and H. Choi. 2007. Adsorption of humic acid onto nanoscale zerovalent iron and its effect on arsenic removal. Environmental Science and Technology 41(6): 2022-2027.3

Graham, R. D., J. S. Alscher, and S. C. Haynes. 1992. Selecting Zinc-efficient cereals genotypes for soils of low Zn status. Plant and Soil 146: 241-250.

Jackson, G. and K. A. Hamson. 2000. Effect of sulfur and zinc on canola yield and nutrient uptake. Agronomy Journal 93: 644-694.

Larcher, W. 2003. Physiological Plant Ecology: Ecophysiology and stress physiology of functional groups, 4th. Edition, Springer: New York.

Malewar, G. U., S. D. Kate, S. L., Walker, and S. Ismail. 2001. Interaction effect of zinc and boron on yield, nutrient uptake and quality of mustard (Brassica juncea) on a typic haplustert. Journal of Indian society of Soil Science 49: 763-765.

Mariotti, M., L. Ercoli, and A. Masoni. 1996. Spectral properties of iron deficient corn and sunflower leaves. Remote Sensing of Environment 58(3): 282-288.

Marschner, H. 1993. Zinc in soil and plant. A.D. Robon (ed). Kluwer Academic Publishers, Dordrcht, the Netherland. Pp: 55- 77.

Moraditochaee, M. 2012. Effects of humic acid foliar spraying and nitrogen fertilizer management on yield of peanut (Arachis hypogaea L.) in Iran. ARPN Journal of Agricultural and Biological Science 7(4):289-293. 


\section{ACCEPTED MANUSCRIPT}

Nardi, S., D. Pizzeghello, A. Muscolo, and A. Vianello. 2002. Physiological effects of humic substances on higher plants. Soil Biology and Biochemistry 34:1527-1536.

Pourgholam, M., N. Nemati, and M. Oveysi. 2013. Effect of zinc and iron under the influence of drought on prolin, protein and nitrogen leaf of rapeseed (Brassica napus). Annals of Biological Research 4 (7): 200-203.

Rajpar, I., M. B. Bhatti, Zia-ul-hassan, A.N. Shah, and S. D. Tunio. 2011. Humic acid improves growth, yield and oil content of Brassica compestris L. Pakistan Journal of Agriculture, Agricultural Engineering and Veterinary Science 27(2): 125-133.

Ravi, S., H. T. Channal, N. S. Hebsur, B. N. Patil, and P. R. Dharmatti. 2008. Effect of sulphur, zinc and iron nutrition on growth, yield, nutrient uptake and quality of safflower (Carthamus tinctorius L.). Karnataka Journal of Agricultural Sciences 21(3): 382-385.

Salwa, A. I. Eisa. 2011. Effect of amendments humic and amino acids on increases soils fertility yields and seeds quality of peanut and sesame on sandy soils. Research Journal of Agriculture and Biological Sciences 7(1): 115-125.

Verlinden, G., B. Pycke, J. Mertens, F. Debersaques, K. Verheyen, G. Baert, J. Bries, and G Haesaert. 2009. Application of humic substances results in consistent increases in crop yield and nutrient uptake. Journal of Plant Nutrition 32:1407-1426.

Wang, H. and J. Y. Jin. 2007. Effects of zinc deficiency and drought on plant growth and metabolism of reactive oxygen species in maize (Zea mays L.). Agricultural Sciences in China 6(8): 988-995.

Ziaeyan, A. H. and M. Rajaie. 2009. Combined effect of zinc and boron on yield and nutrients accumulation in corn. International Journal of Plant Production 3(3): 35-44. 


\section{ACCEPTED MANUSCRIPT}

TABLE 1: Some physical and chemical properties of the soil from the depth of $0-30 \mathrm{~cm}$

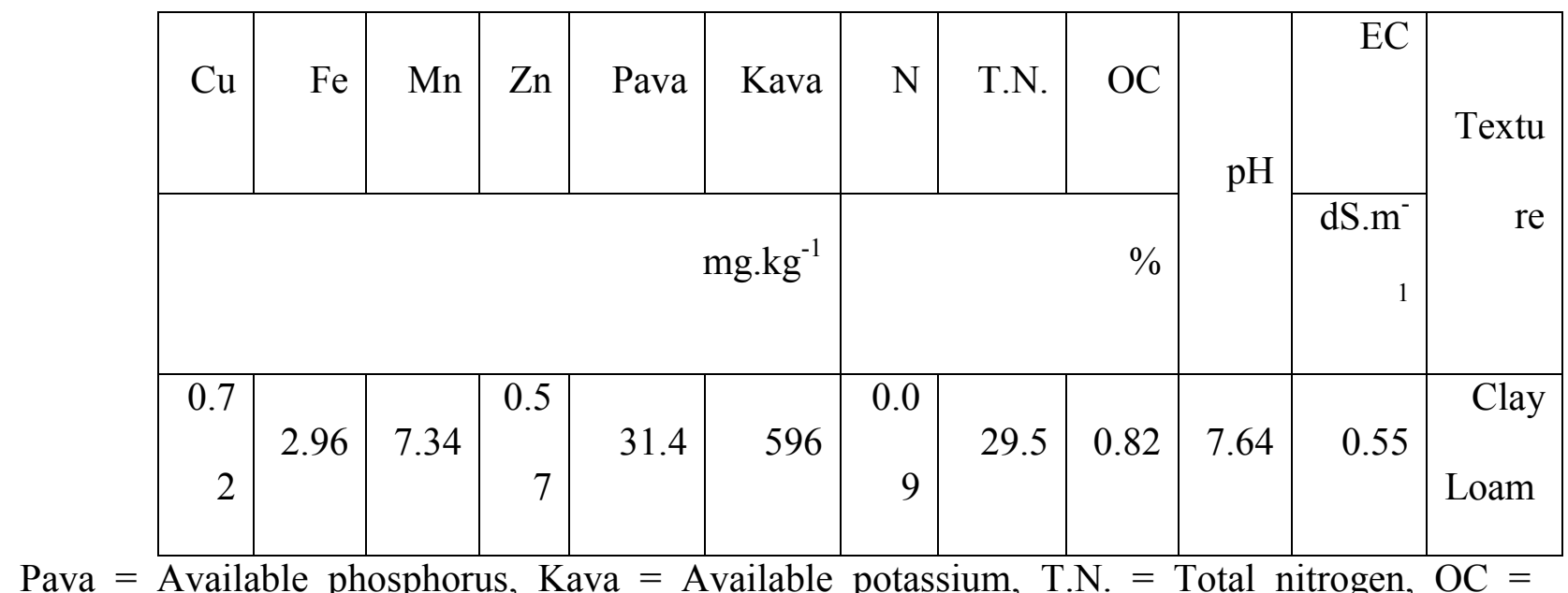

Organic carbon, $\mathrm{EC}=$ Electrical conductivity 


\section{ACCEPTED MANUSCRIPT}

TABLE 2. Analysis of variance of the number of heads per plant, number of seeds per head, 1000 seeds weight, seed yield, oil and protein content in various treatments

\begin{tabular}{|c|c|c|c|c|c|c|c|}
\hline $\begin{array}{l}\text { Source of } \\
\text { Variation } \\
\text { (S.O.V) }\end{array}$ & $\begin{array}{l}\text { Degree } \\
\text { of } \\
\text { freedom } \\
\text { (df) }\end{array}$ & $\begin{array}{l}\text { Number } \\
\text { of heads } \\
\text { per plant }\end{array}$ & $\begin{array}{l}\text { Number } \\
\text { of seeds } \\
\text { per head }\end{array}$ & $\begin{array}{l}1000 \\
\text { seeds } \\
\text { weight }\end{array}$ & $\begin{array}{l}\text { Seed } \\
\text { yield }\end{array}$ & $\begin{array}{l}\text { Oil } \\
\text { content }\end{array}$ & $\begin{array}{l}\text { Protein } \\
\text { content }\end{array}$ \\
\hline Replication & 2 & 2.67 & 2.44 & 0.02 & 6981 & 0.46 & 5.81 \\
\hline Treatments & 5 & $37.63^{* *}$ & $34.4 * *$ & $0.18^{* *}$ & $148465^{* *}$ & $15.53^{* *}$ & $18.37 * *$ \\
\hline Error & 10 & 1.5 & 3.08 & 0.02 & 3352 & 1.04 & 1.8 \\
\hline $\begin{array}{l}\text { Coefficient of } \\
\text { variation } \\
(\mathrm{C} . \mathrm{V})(\%)\end{array}$ & & 4.8 & 6.8 & 4.55 & 7.46 & 6.53 & 5.13 \\
\hline
\end{tabular}

**: significant at $\mathrm{p}<0.01$. 


\section{ACCEPTED MANUSCRIPT}

TABLE 3. Mean comparison of measured traits in different treatments

\begin{tabular}{|l|l|l|l|l|l|l|}
\hline \multirow{2}{*}{ Treatments } & \multicolumn{3}{|l|}{ Traits } \\
\cline { 2 - 7 } & $\begin{array}{l}\text { Number of } \\
\text { capitulum } \\
\text { per plant }\end{array}$ & $\begin{array}{l}\text { Number of } \\
\text { seeds per } \\
\text { capitulum }\end{array}$ & $\begin{array}{l}1000 \text { seeds } \\
\text { weight }(\mathrm{g})\end{array}$ & $\begin{array}{l}\text { Seed yield } \\
(\mathrm{kg} / \mathrm{ha})\end{array}$ & Oil (\%) & $\begin{array}{l}\text { Protein } \\
(\%)\end{array}$ \\
\hline $\begin{array}{l}\text { Control } \\
\text { Humic acid }(1\end{array}$ & $19.4 \mathrm{~d}$ & $19.9 \mathrm{c}$ & $3.12 \mathrm{c}$ & $404.8 \mathrm{e}$ & $36.6 \mathrm{c}$ & $21.56 \mathrm{c}$ \\
\hline $\begin{array}{l}\text { Huma }) \\
\text { 1/ha) }\end{array}$ & $23.3 \mathrm{c}$ & $24.7 \mathrm{~b}$ & $3.47 \mathrm{~b}$ & $666.9 \mathrm{~d}$ & $39.9 \mathrm{~b}$ & $26.13 \mathrm{ab}$ \\
\hline Humic acid $\quad(6$ & $28.8 \mathrm{a}$ & $27.6 \mathrm{ab}$ & $3.82 \mathrm{a}$ & $1019.9 \mathrm{a}$ & $42.6 \mathrm{a}$ & $28.43 \mathrm{a}$ \\
1/ha) & $26.5 \mathrm{~b}$ & $25.5 \mathrm{~b}$ & $3.76 \mathrm{ab}$ & $852 \mathrm{bc}$ & $40.4 \mathrm{~b}$ & $26.77 \mathrm{ab}$ \\
\hline Iron & $25.6 \mathrm{~b}$ & $25.1 \mathrm{~b}$ & $3.51 \mathrm{~b}$ & $756 \mathrm{c}$ & $38.67 \mathrm{~b}$ & $25.85 \mathrm{~b}$ \\
\hline Zinc & $26.8 \mathrm{ab}$ & $30 \mathrm{a}$ & $3.55 \mathrm{ab}$ & $599 \mathrm{~b}$ & $42.8 \mathrm{a}$ & $28.12 \mathrm{ab}$ \\
\hline
\end{tabular}

Means with the same letters are not significantly different at $5 \%$ probability level (LSD). 